\title{
POLÍTICAS E PRÁTICAS DO PROCESSO DE EXPATRIAÇÃO: UM ESTUDO DE CASO EM UMA MULTINACIONAL BRASILEIRA
}

POLICIES AND PRACTICES OF EXPATRIATION PROCESS: A CASE STUDY OF A BRAZILIAN MULTINATIONAL COMPANY

\author{
SHALIMAR - GALLON ${ }^{1}$ \\ PRISCILA SARDI CERUTTI ${ }^{2}$ \\ ALESSANDRA COSTENARO MACIEL ${ }^{3}$ \\ EDUARDO DE CAMARGO OLIVA ${ }^{4}$
}

RESUMO: A expatriação é um processo corrente na condução dos negócios internacionais. No entanto, quando os resultados de um projeto internacional não são alcançados, a falha é atrelada à pessoa enviada ao exterior, em vez de ser percebida como um processo que, por vezes, é mal preparado. Para tanto, essa pesquisa se constitui em estudo de caso qualitativo em uma empresa brasileira que busca analisar as políticas e práticas de Gestão de Pessoas do processo de expatriação. A coleta de dados ocorreu por meio de entrevistas com base em um roteiro semiestruturado, totalizando 23 participantes. Na análise de dados, foi utilizado o software Max-Qda (2007) para auxiliar a organização das categorias de análise, baseada na técnica de análise de conteúdo. Os resultados mostram que a empresa tem desenvolvido e implantado novas políticas e práticas de expatriação, conforme o processo foi sendo desenvolvido. É tratada como uma viagem do empregado e, para tanto, apresenta políticas e práticas de caráter burocrático. Isso acarreta na perda do conhecimento internacional que envolve a expatriação, por não ter políticas e práticas que busquem maximizar o aprendizado dos expatriados na organização.

\section{Palavras-Chave}

Políticas; Práticas; Expatriação; Internacionalização; Gestão de Pessoas.

ABSTRACT: Expatriation is a current process in the conduct of international business. However, when the results of an international project are not achieved, the fault is tied to the person sent abroad, rather than perceived as a process that is sometimes poorly prepared. Therefore, this research constitutes a qualitative case study in a Brazilian company that seeks to analyze the policies and practices of Human Resource Management of the expatriation process. Data were collected through interviews based on a semi-structured script, totaling 23 participants. In the data analysis, the software Max-Qda (2007) was used to help organize the categories of analysis, based on the technique of content analysis. The results show that the company has developed and implemented new expatriation policies and practices as the process was developed. It is treated as an employee trip, and for that, it presents bureaucratic policies and practices. This entails the loss of international knowledge

\footnotetext{
Data de submissão: 20/08/2017 Data de aceite: 17/06/2018 Data de publicação: 08/08/2018

1 Faculdade Meridional - IMED

2 Faculdade Meridional - IMED

3 Faculdade Meridional - IMED

4 Universidade de São Caetano do Sul
} 
that involves expatriation, as it does not have policies and practices that seek to maximize expatriate learning in the organization.

\section{Keywords}

Policies; Practices; Expatriation; Internationalization; Human Resources Management.

\section{INTRODUÇÃO}

O processo de expatriação é a transferência de um profissional de uma empresa sediada em um determinado país, para trabalhar, por tempo determinado ou não, em uma unidade desta empresa localizada em outro país (Zwielewski \& Tolfo, 2016). É, portanto, um processo corrente na condução dos negócios internacionais, tendo importância na sua expansão global.

A demanda por empregados da matriz para exercer uma atividade nas subsidiárias é bastante usual, pois estes estão familiarizados com a cultura, ambiente e políticas da organização e acabam assumindo atribuições importantes para a internacionalização empresarial. Esse processo normalmente acontece quando as empresas buscam internacionalização da gestão; integração global; aumento dos conhecimentos de certa equipe para desenvolver um projeto ou uma unidade específica; desenvolvimento da liderança de gestores; coordenação e controle de suas unidades, geograficamente dispersas; aumento da diversidade estratégica da Gestão de Pessoas (GP) frente aos mercados globais; desenvolvimento de novas técnicas e processos organizacionais; controle das subsidiárias por meio de empregados de sua confiança; inovação; transferência de tecnologia; controle ou reforço da cultura organizacional; enquadramento das pessoas nos objetivos da empresa; expansão de novos mercados; e compreensão das preferências do mercado a fim de aumentara participação nos mercados de atuação (Bartlett \& Ghoshal, 1992; Black \& Gregersen, 1999; Tanure, Evans, \& Pucik, 2007; Freitas, 2010; Freitas \& Dantas, 2011).

Quando os resultados de um projeto internacional não alcançam os objetivos propostos, a falha é atrelada à pessoa enviada ao exterior, em vez de ser percebida como inerente ao empreendimento - um projeto de alto risco e, por vezes, mal preparado (Mccall \& Hollenbeck, 2003). Torna-se evidente, portanto, analisar esse processo que acaba sendo considerado pelas organizações como uma simples viagem do empregado. De fato, a expatriação não é apenas o deslocamento de um empregado para outro país; porém, este processo vem sendo negligenciado no âmbito empresarial.

Deste modo, o processo da expatriação demanda estruturação para que o empregado que sairá em missão, saiba qual é o objetivo da viagem e tenha segurança de seu retorno para a empresa. É um processo que envolve diversos procedimentos, estratégias e pessoas, demandando uma estrutura por parte da GP de origem e da GP de destino. A expatriação compreende práticas como recrutamento, preparação e adaptação da família, treinamento técnico e cultural, fornecimento de documentos a todos os envolvidos, gestão de desempenho, carreira e conhecimento, remuneração, suporte psicológico, entre outras a serem levantadas. Tais práticas envolvem diferentes momentos: a ida; o período de trabalho no exterior; e o retorno do expatriado, no entanto, não há consenso na literatura sobre quais práticas fazem parte desse processo e de quais etapas.

Coerente a isso, um levantamento realizado por Gallon e Antunes (2015) sobre a publicação de artigos sobre políticas e práticas de expatriação, no período de 2008 a 2012, 
mostram que há grande ênfase no estudo de uma parte específica do processo (o deslocamento do empregado para o país de destino, ou seja, na expatriação), corroborando para a importância de entender o processo na íntegra. Assim, as principais políticas e práticas abordadas nos artigos levantados foram recolocação do repatriado no mercado de trabalho, criação de vínculos com o expatriado para que ele possa se identificar com a subsidiária; gestão de acompanhamento (durante o processo de expatriação); programas de mentoring e treinamento (técnico e cultural) para o expatriado e para a família; recrutamento e seleção (análise do perfil e da personalidade); visitas com maior frequência na matriz durante a expatriação; transferência de conhecimento; desenvolvimento do executivo da GP; benefícios (auxílio financeiro para a mudança); retorno financeiro; gestão de carreira; gestão de desempenho; adaptação cultural; gestão de justiça social; programas de reciclagem; gestão de competências; gestão de comunicação; e motivação para expatriar (Gallon \& Antunes, 2015).

Levando em consideração a proposta deste estudo, é importante mencionar a respeito das lacunas existentes na literatura que revelam a necessidade de melhor compreender as políticas e práticas de expatriação. Por isso, indaga-se: quais as políticas e práticas de GP são importantes no processo de expatriação em uma empresa brasileira? Assim, o presente estudo busca analisar as políticas e práticas da GP do processo de expatriação em uma empresa brasileira. Acredita-se que esse estudo proporcionará maior conhecimento acerca da GP Internacional (GPI), com o desenvolvimento de uma discussão acerca da teoria e prática sobre o tema.

Para tanto, as próximas seções apresentam as políticas e práticas de GP no processo de expatriação e, posteriormente, expõem-se os procedimentos metodológicos da pesquisa. A análise das políticas e práticas de expatriação da empresa brasileira estudada e as considerações finais são as últimas seções desse estudo.

\section{Políticas e Práticas de Gestão de Pessoas no Processo de Expatriação}

Nessa seção serão abordadas as políticas e práticas do processo de expatriação que foram encontradas na literatura e que compõem as diversas etapas da expatriação (preparação, expatriação em si e repatriação), enfatizando que não há na literatura a divisão dessas políticas e práticas a cada etapa. Para tanto, quando se fala em processo de expatriação compreendem-se essas três etapas.

Deste modo, primeiramente, as organizações analisam quem deve ser enviado para realizar o trabalho, porém, dentro do planejamento do processo de expatriação, deve-se ser identificado o trabalho a ser executado, para depois verificar as pessoas com possibilidade de serem enviadas. Assim, a estratégia e o objetivo da missão podem determinar quantos expatriados são necessários e como serão posicionados na subsidiária (Mccall \& Hollenbeck, 2003). Por isso, a questão do processo de expatriação começa com a determinação da estratégia e do objetivo antes da determinação das políticas e práticas.

Frente a isso, pesquisas mostram que entre $20 \%$ e $40 \%$ das pessoas enviadas para o exterior retornam prematuramente da sua missão (Mendenhall \& Oddou, 1985; Tung, 1981). Esse insucesso do processo de expatriação tem sido relacionado com a falta de interesse, respeito e a sensibilidade cultural; empatia; competências; atitudes sociais; contexto global no qual os expatriados estão inseridos; políticas e práticas organizacionais do processo; insatisfação com o trabalho; dificuldade de adaptação ao país estrangeiro; planejamento inadequado para expatriação e repatriação do empregado e da sua família; 
aspectos financeiros e benefícios; critérios de seleção que não levam em conta a missão a ser desempenhada, mas critérios predefinidos de seleção; repatriação; e carreira profissional (Black \& Gregersen, 1999; Deresky, 2004).

Vale destacar, conforme apontam Kubo e Braga (2013), que o conceito de sucesso em expatriação vem sendo questionado, tendo em vista que o expatriado pode não ter um bom desempenho, mesmo permanecendo até o final da designação que Ihe foi proposta. Porém, os autores afirmam que a pesquisa em torno dessa temática ainda é escassa e a operacionalização do conceito como a taxa de retorno antecipada tem sido a mais utilizada. Para tanto, a pesquisa de Black e Gregersen (1999) com 750 americanos expatriados reforçam o apontamento de Kubo e Braga (2013). Aproximadamente um terço dos pesquisados que completaram a expatriação não corresponderam às expectativas da empresa em relação ao seu desempenho. Ademais, dentro de um ano após a repatriação, um quarto dos entrevistados deixou a empresa, sendo que essa taxa de rotatividade é o dobro da taxa de gestores não expatriados (Black \& Gregersen, 1999).

Nesse sentido, para amenizar os insucessos da expatriação, Pereira, Pimentel e Kato (2004) sugerem que a seleção e o treinamento dos expatriados levem em consideração alguns critérios: (1) avaliar o perfil cultural do expatriado, incluindo a análise de adaptação da família em outro país; (2) dar preferência, para essa missão, ao expatriado e à família que já tiveram outras experiências culturais; (3) elaborar programas de comunicação que possibilitem ao expatriado e à família desenvolverem a habilidade de comunicação na língua do país de destino, sendo esse programa realizado anteriormente à missão e tendo continuidade por algum período, no país estrangeiro; (4) dar apoio ao expatriado e à família, no período de adaptação, incluindo decisões sobre escola dos filhos, cursos intensivos de língua do país estrangeiro, cursos que possibilitem enxergar as diferenças culturais, tanto em relação à língua como aos costumes, pois a diferença cultural entre alguns países é grande e o que em um lugar é considerado normal, em outro pode ser um desrespeito.

Para a atribuição do expatriado, Schuler, Budhwar e Florkowski (2002) destacam que a empresa precisa avaliar certas dimensões de desempenho (não especificamente ligadas ao trabalho), tais como qualidades interpessoais e interculturais; sensibilidade às normas estrangeiras, leis e costumes; adaptabilidade às condições incertas e imprevisíveis; integração ao local de acolhimento com as unidades da empresa. As interações de uma estratégia empresarial complexa, as múltiplas culturas e os meios de formação variados dos expatriados causam impacto em todo o processo (Mccall \& Hollenbeck, 2003).

Outro fator importante é o acompanhamento da família no processo de expatriação. A adaptação do cônjuge e dos filhos pode influenciar no fracasso da missão internacional, devido a um não ajustamento cultural, pois a família acaba por adaptar-se com mais dificuldades. Além de ter sua rede de relacionamentos interrompida, não possui das mesmas vantagens que o expatriado, que ao trabalhar obtém uma rede de relacionamentos diária (Schulze \& Bustamante, 2015).

Um assunto pouco explorado nos estudos sobre expatriação é a questão da saúde do empregado. Além de todos os exames e vacinas preparatórias para a viagem, é necessário providenciar, no país de destino, um plano de saúde para o expatriado e sua família e também atentar para possíveis problemas psicológicos. Rego e Cunha (2009) questionam: em que medida as viagens frequentes dos expatriados podem prejudicar sua saúde e seu desempenho? Quais são os fatores de estresse, antes, durante e depois das viagens? Como as empresas podem ajudar os expatriados a gerirem os fatores de estresse das viagens? 
Essas questões indicam que, muitas vezes, as empresas não têm consciência de que devem estar atentas a possíveis problemas causados pelas viagens.

Depois que o expatriado foi selecionado, é importante que a empresa the esclareça as expectativas e as metas de seu desempenho e evidencie como isso se articula com a estratégia organizacional (Harzing, 2002). Nesse momento, também deve ser esclarecida a perspectiva de crescimento que a pessoa terá, se os objetivos traçados forem alcançados, ou simplesmente conscientizá-la sobre o cargo que terá na volta. Igualmente devem ser apresentados a proposta financeira e os benefícios agregados à expatriação.

Em muitos casos, empresas utilizam, predominantemente, a combinação de vários métodos, baseando a definição salarial nas práticas do país de origem e de acolhimento, na estrutura salarial da empresa e na negociação individual. O pacote salarial do expatriado é pago na moeda do país de acolhimento e a remuneração é revista uma vez por ano e, nas demais empresas, a revisão é feita se ocorrer alguma mudança no estatuto da expatriação, por exemplo, no tamanho da família ou no nível das funções do empregado. A maioria das empresas não ajusta os salários de acordo com as flutuações da moeda. São efetuados ajustes na remuneração fixa do empregado tendo em conta o diferencial de custo de vida entre a cidade de origem e a cidade de destino, com a finalidade de manter seu poder de compra (Mercer, 2010).

Além de as propostas financeiras ao expatriado, cabe ressaltar a importância do treinamento técnico e gerencial, que é realizado antes da expatriação. Muitos empregados assumem cargos mais altos do que possuíam no país de origem, desempenhando atividades gerenciais e assumindo diversos desafios (Gallon, 2011). Nesse sentido, a família também passa por treinamento cultural. Rego e Cunha (2009) citam algumas práticas que a GP pode oferecer: apoio anterior à partida; aconselhamento permanente antes, durante e depois da missão; formação linguística; formação cultural; programas de mentoria antes e durante a missão, bem como depois da repatriação; criação de mecanismos de comunicação que permitam manter contato com a empresa e o país de origem (acesso a internet, viagens regulares); criação de cursos de informação (cultural, social e política); aconselhamento psicológico em momentos de grande estresse e ansiedade; apoio ao cônjuge na procura de colocação no país de destino e aconselhamento para sua carreira e formação.

Rego e Cunha (2009) sublinham que os futuros expatriados também devem receber treinamento condizente com as características de seus futuros subordinados. Uma das maneiras de a empresa disponibilizar tal formação é ter conhecimento da experiência de antigos expatriados, em missões similares, no mesmo país. Por isso, a importância de a empresa ter conhecimento do feedback dos expatriados, da gestão de conhecimento e das atividades por eles desenvolvidas. Isto torna possível conhecer as atividades dos expatriados e passar informações para os futuros expatriados. Com treinamento apropriado, os gestores expatriados podem aprender a se comunicar mais eficazmente com seus subordinados.

Para que o trabalho seja realizado de acordo com a necessidade da empresa, é importante entender a língua local e o significado peculiar das palavras. Não basta saber traduzir literalmente as palavras de uma língua para a outra e nem ser proficiente na interpretação do aparente significado de determinados comportamentos, já que estes podem adquirir diferentes significados em diferentes contextos. As pessoas de culturas diversas têm os próprios quadros de referência, o que pode povoar a comunicação de equívocos gerados pela interpretação inadequada de sinais verbais e não verbais. 0 ajustamento sociocultural é o modo como o expatriado adquire competências específicas da 
cultura local, é capaz de se relacionar com as pessoas locais e é proficiente na gestão das situações cotidianas (Rego \& Cunha, 2009).

Deste modo, trabalhar no exterior, é uma experiência que expõe o profissional a condições de vida diferentes do seu país de origem, impactando, muitas vezes, na reestruturação da sua rotina. Em alguns países, poucas coisas podem ser resolvidas por telefone, e atividades corriqueiras, como solicitar documentos de identidade, exige obrigações legais e complexas. Assim, os profissionais sofrem com os choques culturais e, muitas vezes, apresentam sinais de sofrimento, isolamento e medo (Prestes \& Rosembrock, 2015). Por isso, é importante que as empresas compreendam que não é adequado usar a mesma gestão em diferentes países, pois há aspectos institucionais, políticos e econômicos que exercem maior ou menor influência na cultura.

A GP é carente de práticas, principalmente, para reter o líder após uma expatriação, pois as organizações tendem a ser reativas em vez de estratégicas (Lazarova \& Caligiuri, 2004). Ou seja, as empresas não planejam todo o processo de expatriação, somente a ida do empregado e, quando se deparam com a necessidade de repatriar uma pessoa, o fazem sem um planejamento traçado. Por isso, um bom planejamento de repatriação começa com um esforço para gerir as expectativas dos expatriados mesmo antes deles saírem para a missão. As organizações devem fazer uma tentativa de reter os expatriados sobre as expectativas durante e depois da missão internacional (Lazarova \& Caligiuri, 2004).

As organizações têm, no entanto, o foco voltado para o apoio aos processos de expatriação, por meio de atividades de treinamento e desenvolvimento. 0 acompanhamento dos processos de expatriação está baseado em práticas informais e, para os expatriados brasileiros, o valor da experiência internacional não é medido exclusivamente em termos de remuneração e de benefícios diretos (Vianna \& Souza, 2009). Esses dados mostram que as empresas ainda têm dificuldades em gerenciar a expatriação, principalmente pela informalidade de suas práticas (Vianna \& Souza, 2009; Lima \& Braga, 2010). Elas acreditam que os aspectos financeiros compensam os incômodos de uma expatriação, o que não corresponde à visão dos expatriados (Vianna \& Souza, 2009).

As expatriações englobam as exigências do mercado de trabalho e geraram, nos empregados, experiências que afetam suas expectativas de evolução pessoal e profissional; de representações sociais; de avaliação das próprias competências (Homem \& Dellagnelo, 2006). Esse é um dos motivos pelos quais os expatriados passam a valorizar mais a experiência internacional e percebem que os aspectos financeiros não são tão importantes frente ao aprendizado adquirido. Isso acaba refletindo na valorização da carreira que está relacionada aos altos índices de desligamento de expatriados da empresa (Gallon, Scheffer, \& Bitencourt, 2013). Entretanto, as empresas devem tomar iniciativas para capturar o conhecimento dos expatriados, sempre que possível, e buscar mais formas de motivá-los a permanecer na empresa (ou, pelo menos, ficarem ligados a ela) após a expatriação (Tungli \& Peiperl, 2009).

As principais políticas e práticas de GP na repatriação apontadas no estudo de Lima e Braga (2010) foram atualização de informações sobre as mudanças na organização; pagamento de viagens ao país de origem; treinamento cultural antes da expatriação; suporte financeiro para realização da mudança (na expatriação e repatriação); e realocação no mercado de trabalho, caso não houvesse um cargo para a pessoa na organização no seu retorno. Esses apontamentos mostram que mesmo o estudo que se propõe a analisar as políticas e práticas de GP na repatriação aborda as diferentes etapas do processo da 
expatriação, corroborando ao fato de que as políticas e práticas de expatriação, por vezes, se misturam em uma única análise.

As práticas de GP utilizadas pelas empresas para garantir o sucesso do processo de repatriação e retenção dos repatriados, não são estratégicas e estão relacionadas com o suporte operacional ao repatriado. As práticas que poderiam solucionar ou minimizar os principais problemas que os repatriados enfrentam não são adotadas, pois a maioria das empresas possui políticas de repatriação estruturadas e documentadas, mas, em geral, não são divulgadas aos empregados (Lima \& Braga, 2010).

Por fim, é importante ter clareza que a expatriação passa por diversos obstáculos. Fica claro que o processo se trata de um duplo desafio: tanto para o profissional que será expatriado, quanto para quem atua na GPI. Os profissionais que trabalham na GP precisam estar sempre atentos às mudanças organizacionais para se prepararem adequadamente às transferências, minimizando assim as chances de fracasso com a missão internacional (Sebben, 2009).

\section{Procedimentos Metodológicos}

A pesquisa de abordagem qualitativa é um estudo de caso (Yin, 2010) em uma empresa brasileira, pertencente ao setor industrial e com matriz no estado de Santa Catarina (SC), aqui adotando o nome fictício de Elétrica. Justifica-se a escolha dessa empresa pelo destaque que possui em seu país de origem, além de estar internacionalizada há mais de 20 anos, estando presente em mais de 100 países dos cinco continentes.

Inicialmente, foi desenvolvido um estudo exploratório com indivíduos de diferentes organizações internacionalizadas que receberam a denominação de participantes coadjuvantes. Eles colaboraram com a pesquisa no intuito de dar suporte e melhor entendimento às respostas dos entrevistados protagonistas (empregados da empresa estudada). Essa etapa também buscou fazer um levantamento sobre o panorama da GP no contexto internacional e da expatriação em organizações internacionalizadas.

Na pesquisa realizada na Elétrica, por demandar um público bem específico (pessoas que tivessem sido expatriadas e que tivessem conhecimento ou contato com a expatriação, GP e internacionalização), o número de pessoas disponíveis para serem entrevistadas mostrou-se reduzido. Não foi, portanto, usado nenhum critério adicional de escolha dos entrevistados (como sexo, idade ou cargo). Todas as pessoas que foram indicadas pela empresa e entrevistados foram contatadas para participarem da pesquisa, cabendo a elas aceitarem ou não contribuir com o estudo. Assim, também fizeram parte da pesquisados expatriados que estavam em outras subsidiárias, fora do contexto Brasil, mas que possuem experiência e conhecimento internacional.

A coleta dos dados foi realizada por meio de entrevista com base em um roteiro semiestruturado (tanto para os entrevistados coadjuvantes e protagonistas), desenhado a partir do referencial teórico exposto na presente pesquisa e foi sendo organizado conforme o campo era explorado. Foram utilizadas ferramentas de conversação via internet, como o Skype que oferece a possibilidade de realização de entrevistas individuais (Janghorban, Roudsari, \& Taghipour, 2014), para auxiliar na condução das entrevistas ou para retomar algum ponto da entrevista que precisava ser esclarecido, encontrando-se a pessoa a grande distância. Além das entrevistas, foram realizadas consultas a documentos, sites, material publicitário, com o objetivo de triangular os dados, na qual múltiplas fontes de informação 
são utilizadas, para melhor compreender o fenômeno que está sendo estudado (Yin, 2010), dando relevância igual para todos os dados (Flick, 2009).

A pesquisa iniciou em agosto de 2012, com o estudo exploratório, e em novembro e dezembro de 2013 foram realizadas as entrevistas com os empregados da Elétrica, totalizando 23 entrevistas realizadas, como mostra a Tabela 1. Dos entrevistados, oito pessoas eram da GP; 13 eram expatriados; 13 eram gestores, considerando que alguns entrevistados eram da GP e expatriado, gestor e expatriado ou da GP e gestor. Nenhum dos entrevistados era da GP, gestor e expatriado.

Tabela 1

Quantidade de entrevistados

\begin{tabular}{l|c|c}
\multicolumn{1}{c|}{ Sujeitos } & Elétrica & Coadjuvantes \\
\hline Entrevista realizada pessoalmente & 9 & 12 \\
\hline Entrevista realizada por Skype & 1 & 1 \\
\hline Estrangeiros & 1 & 6 \\
\hline Brasileiros & 9 & 7 \\
\hline Gestão de Pessoas & 3 & 5 \\
\hline Expatriados & 7 & 6 \\
\hline Gestores & 5 & 8 \\
\hline Total & $\mathbf{1 0}$ & $\mathbf{1 3}$ \\
\hline
\end{tabular}

Nota. Fonte: Elaborada pelos autores (2017).

As empresas (nomes fictícios) que forneceram os entrevistados coadjuvantes foram a Metálica (Caxias do Sul - Rio Grande do Sul - RS), a Ferro (Porto Alegre - RS), a Equipe Psico (Florianópolis - SC), a Plástico (Cascais - Portugal), a Turismo (Lisboa - Portugal), a Energia (Lisboa - Portugal), a Cimento (Lisboa - Portugal) e a Exportação (Lisboa - Portugal). Na Metálica, foram entrevistadas três pessoas; na Ferro, duas pessoas; e nas demais empresas, uma pessoa em cada organização.

Para a análise das informações, foi utilizada a técnica de análise de conteúdo (Bardin, 2009). Após a coleta de dados, em um primeiro momento, foi realizada a transcrição das entrevistas e uma leitura flutuante a fim de estruturar as categorias. A análise partiu de quatro macro categorias a priori: gestão de pessoas, internacionalização, expatriação e diferenças entre países, visto que esses foram os temas norteadores da pesquisa. Conforme a categorização das informações era desenvolvida, as categorias primárias foram surgindo naturalmente. A organização e reestruturação das categorias ocorrem por meio do software Max-Qda versão 2007, o que possibilitou melhor visualização das análises da pesquisa.

Durante e no final do processo de categorização, era realizada nova organização das categorias, caracterizando um processo contínuo. Assim, as quinze categorias iniciais foram reduzidas para oito categorias. Ressalta-se que esse é um estudo oriundo de uma tese de doutorado e, nesse artigo, será exposta somente a categoria a análise das políticas e práticas do processo de expatriação com base nos achados das pesquisas expostas no referencial teórico (Tung, 1981; Mendenhall \& Oddou, 1985; Black \& Gregersen, 1999; Schuler et al., 2002; Harzing, 2002; Mccall \& Hollenbeck, 2003; Deresky, 2004; Lazarova \& Caligiuri, 2004; Pereira et al., 2004; Homem \& Dellagnelo, 2006; Tanure et al., 2007; Vianna, 2008; Rego \& Cunha, 2009; Sebben, 2009; Tungli \& Peiperl, 2009; Vianna \& Souza, 2009; Lima \& Braga, 2010; Mercer, 2010; Gallon, 2011; Kubo \& Braga, 2013; Gallon et al., 2013; Prestes \& Rosembrock, 2015; Gallon \& Antunes, 2015; Schulze \& Bustamante, 2015), a qual é abordada na próxima seção. 


\section{Análise das Políticas e Práticas de Expatriação}

A Elétrica é líder na América Latina e está entre as maiores empresas do mundo na fabricação de elétricos industriais, sendo a décima sexta transnacional brasileira (Fundação Dom Cabral, 2010). Têm 14 empresas fabris no Brasil e 14 empresas no exterior, contando com aproximadamente 28 mil empregados dos quais seis mil estão no exterior. A empresa começou seu processo de internacionalização, em 1988, por meio de exportações. Entretanto, a primeira filial surgiu, em 1991, nos Estados Unidos da América (EUA). Em 2002, adquiriu a empresa Motores, em Portugal, tradicional fabricante de elétricos especiais. Essa aquisição proporcionou-lhe assumir a posição de líder de mercado em Portugal e dar continuidade a uma presença destacada nos principais setores de atividade das engenharias (Cechella, 2009). Essa foi a primeira fábrica na Europa, a qual conta, atualmente, com mais de 260 empregados (Empresa Elétrica, 2014).

Na década de 1990, foi realizada a primeira expatriação da empresa Elétrica, com destino aos EUA. Devido a inexperiência internacional, a baixa tecnologia e o lento acesso as informações, os entrevistados brasileiros relataram dificuldades nesse processo. No entanto, conforme exemplificam o E13 (Vice-Presidente EUA), o E19 (Gerente de Vendas Europa) e o E12 (Diretor Internacional Brasil), com o aumento da frequência da expatriação, a empresa foi aprimorando as viagens e adquirindo experiência. Isso se deve a maior atuação da GP relacionada com a reestruturação da GPI na matriz, que acaba "dando suporte a assuntos diversos de GP nas unidades do exterior" (E16 - Analista de GPI Brasil).

O E13 (Vice-Presidente EUA) concorda com o entendimento de suporte da GPI porque "tem muita gente que considera que, na expatriação, tu passas a ser um filho da empresa e eu acho que é um pouco de exagero". O depoimento do E19 (Gerente de Vendas Europa) corrobora com o exposto, no entanto, expõe as dificuldades de alguns expatriados e a informalidade das práticas de expatriação, em função do amadurecimento da GPI, conforme apresentadas em estudos anteriores de Vianna e Souza (2009) e Lima e Braga (2010).

As pessoas que entraram antes aqui, como o E10 (Supervisor de vendas internacionais Brasil), que entrou antes de mim, ou o E17 (Gerente de Mercado Internacional Europeu), teve um pouco de dificuldades, ele tem alguns traumas no processo de expatriação, que foram os primeiros, aí não sabiam o que fazer. Demorou para aprender e não tinham pessoas qualificadas e dedicadas ao expatriado talvez para passar essas informações. Mas isso aí é um pouco da inexperiência do pessoal, no ser expatriado e não receber a instrução correta. Eu já citei algumas pessoas no background que estão aprendendo com isso, no setor de expatriação, e que ajudam e auxiliam um pouco [tais como o E16 (Analista de GPI Brasil) e a Daniela]. É simples, então, basta ter calma e fazer a coisa do jeito que tem que ser feita. Então, tem um canal de comunicação, toda hora que você precisa algum apoio, alguma coisa, você tem que contar. Eu procuro contar o mínimo possível. No meu processo, foi extremamente simples. Me deram todo o apoio que eu precisava lá no Brasil. Claro que tem muita coisa que você não vai lá: 'eu sou expatriado', esqueço que existe um departamento que vai tratar disso para mim e vou tratar imigrações sozinho. Não é assim. Você tem que tratar seus vistos, da tua entrada no país, tem que tratar das tuas coisas, em termos particulares, lá no Brasil e aqui também. Mas deram muito apoio, tanto na chegada, as pessoas que já estavam aqui de expatriados, sempre facilitou um pouco para mim. E a GP do Brasil, na parte de estruturação do meu visto, da entrada aqui em Portugal, me deram todo o apoio, e eu calmamente fui traçando minhas linhas (E19 - Gerente de Vendas Europa). 
O E17 (Gerente de Mercado Internacional Europeu) conta que enfrentou os problemas em sua expatriação sem o apoio da empresa: "acabei me virando sozinho". As dificuldades enfrentadas foram de caráter operacional, contratual, de saúde e familiar. Ele ressalta que percebe melhorias nos processos de expatriação realizados recentemente, porém, contrariando o E13 (Vice-Presidente EUA) e o E19 (Gerente de Vendas Europa), acredita que a empresa precisa melhorar a atuação da GPI e destaca que "quando tu encontras algumas dificuldades, dependendo de que posição tu estás dentro da empresa, é um pouco mais difícil ou não" (E17 - Gerente de Mercado Internacional Europeu), sinalizando as diferentes práticas de expatriado em função do cargo ocupado. O E14 (Assistente Técnico Europa) concorda com essa última opinião e entende que "há diferenças entre países, mas eu acho que, às vezes, não são tão grandes do que as diferenças que existem entre níveis" (E14 Assistente Técnico Europa). Esse último entrevistado relata que tem contato com os expatriados de diversas localidades, como Inglaterra, França, Itália, Portugal e EUA, e esse aspecto gera um descontentamento comum entre eles. Essas diferenças não foram encontradas em estudos anteriores, mostrando que a função exercida na expatriação tem impacto nas políticas e práticas no processo de expatriação.

Ciente desse contexto, a empresa conta com "uma política de práticas internacionais que é um documento super restrito e ele não é disponibilizado, só nós da GP temos acesso" (E16 - Analista de GPI Brasil). Essa restrição, apesar de não ter sido abordada diretamente nas entrevistas, ocorre para evitar conflitos entre os expatriados por causa dos benefícios concedidos. No entanto, frente aos relatos expostos, entende-se que a política de expatriação desenhada pela empresa não tem sido aplicada em sua plenitude. Os contratos de expatriação acabam assumindo um caráter burocrático, mais no intuito de preservar a empresa, do que para dar suporte aos empregados no exterior. Essa situação é percebida no relato do E19 (Gerente de Vendas Europa): "eu nunca tive problema de doenças, de visto, de nada. Nunca tive que recorrer a eles. O dia que tiver alguma coisa, com certeza, eu vou recorrer e eles vão ter que me dar apoio". Isso mostra que até os aspectos mais básicos, como a saúde, não estão claramente explicitados, submetendo o empregado a possíveis contratempos.

A GPI no Brasil é ampla e com diversas ênfases. O E11 (Diretor de GP Corporativa Brasil) relata que antes de sua gestão, essa área era denominada como 'área dos expatriados'. A partir de maio de 2013, "eu coloquei ela um pouco mais em evidência e chamei de GPI" (E11 - Diretor de GP Corporativa Brasil). Atualmente, a GPI é composta "mais ou menos assim: uma colega minha cuida mais da parte da imigração, visto, documento, passagem e registros administrativos; uma outra colega, a Daniela, cuida mais dos expatriados, reembolso e benefícios e eu também cuido dos expatriados e dos executivos" (E16 - Analista de GPI Brasil). Essa estrutura permite que a área subsidie diversos benefícios e auxílios para os expatriados. A GP das subsidiárias é voltada para os processos operacionais e também atua como GPI, a qual, em alguns momentos, está ausente na adaptação dos expatriados.

O E16 (Analista de GPI Brasil) apresenta questões práticas que dificultam a ação da GP em relação à preparação da expatriação e a seus objetivos. O contexto empresarial muda rapidamente, impedindo que a empresa trace um planejamento de treinamento completo para todos os expatriados. Essa estrutura só começa a ser visualizada quando há direcionamento da empresa ou perspectiva de carreira para essa pessoa. Nestas circunstâncias, empresa e expatriado sabem o percurso a ser realizado e que o investimento não será perdido. No entanto, isso não ocorre com empregados de cargos mais baixos os 
quais, frequentemente, trocam de emprego. Assim, o E16 (Analista de GPI Brasil) relata que a GPI é uma área "muito reativa nesse sentido [de dar treinamento], poderia preparar um pouco melhor as pessoas para isso. Seria o ideal para empresa, preparar as pessoas, fazer elas passarem por várias áreas antes. Mas, até tu preparar, em dois anos, essa pessoa já saiu da empresa". Esse contexto corrobora para o entendimento de miopia da GPI apontado por Lima e Braga (2010), na qual a GPI é reativa e com atuação burocrática, sem uma visão estratégica.

Apesar de a dificuldade de um implantar um treinamento em longo prazo, há carência de instruções pontuais sobre a expatriação. Um fator que chamou a atenção foi às instruções relativas ao cargo assumido no exterior e as particularidades culturais que não são sinalizadas para o expatriado, o que pode dificultar o trabalho do empregado. Essa prática é apontada como importante por Pereira et al. (2004), Gallon (2011) e Rego e Cunha (2009). O relato seguir mostra tal situação.

Tinha um vendedor no sul que o diretor comercial antes de eu chegar tinha dado
uma lista de clientes que ele não poderia visitar. Esse vendedor do sul era um
pouco acomodado e como ele era empregado, não era comissionado, se ele não
vendesse, ele ganhava igual se ele vendesse. Eu entrei lá e simplesmente não me
deixaram a par disso, o diretor comercial não me disse isso, ninguém me avisou
sobre isso, simplesmente, depois que eu estava cobrando desse vendedor o
trabalho dele é que eu fui saber (...) Como eu vou passar um vendedor $100 \%$, se ele
não pode visitar os clientes na região!? Coisas desse nível aconteceram lá. Então,
para você ver o nível do estresse, do meu dia a dia de trabalho, como é que eu vivi,
posso te afirmar que foi durante quatro anos. Então, para mim foi uma coisa que
me marcou muito, foi muito pesado (E10 - Supervisor de vendas internacionais
Brasil).

A questão de treinamento, objetivo e retenção do expatriado ainda não está clara para a empresa e mostra diferentes vertentes. O E19 (Gerente de Vendas Europa), em sua percepção de expatriado, acredita que a empresa vê esse processo como uma forma de treinamento e desenvolvimento do empregado, a fim de incrementar o quadro pessoal da empresa com pessoas internacionalizadas, visando ter condições de competir no cenário global. Já o E16 (Analista de GPI Brasil) entende que a expatriação visa suprir uma necessidade da empresa, conforme expõe o seu relato:

A Elétrica comprou uma fábrica nos EUA, em 2011 no final do ano. Então, era importante ter alguém da área comercial lá, que conhecesse os produtos aqui do Brasil. Então, se mandou um engenheiro da área comercial para lá, mas porque era importante, não era para desenvolver esse cara, entendeu? Pode até ser que tenha um objetivo secundário, mas o principal é para suprir uma necessidade, uma demanda.

No entanto, o E15 (Ex-Diretor Internacional Brasil) ressalta a importância de analisar o que essas pessoas estão agregando para a empresa e, a partir disso, buscar reter e valorizar o empregado ou dar a liberdade para que ele procure outras empresas, no caso de um eventual descontentamento com o trabalho, no retorno da expatriação. Ressalta-se que a avaliação do que o empregado agregou para a empresa não é uma prática formalizada e pouco explorada na literatura de expatriação, a partir de uma análise dos resultados do levantamento realizado por Gallon e Antunes (2015). Ademais, o E15 (Diretor do Mercado Internacional) entende que a empresa tem valorizado os expatriados, oportunizando lhes 
uma melhor colocação no Brasil. Isso não depende só da empresa, mas da ocasião, pois é difícil conciliar as expectativas de todos os expatriados no momento da repatriação, como também apontam Gallon et al. (2013). Tal situação mostra o caráter informal do processo, muito em função da dinamicidade do contexto empresarial, o qual depende de outros fatores, como relata o E12 (Diretor Internacional Brasil):

\begin{abstract}
É difícil você tratar como uma regra (...). Tem gente retornando porque a empresa solicitou, retornando com promoção, bem posicionado dentro da empresa, tendo todos os investimentos, o retorno sob o teu investimento dos anos que você trabalhou lá fora. Têm outras pessoas que solicitam para voltar e nem sempre coincide o momento que elas querem voltar com o melhor que a empresa pode Ihes oferecer. Aí a pessoa fica um pouco frustrada e diz: passei três, cinco, seis anos lá fora e volto e não conquistei muita coisa. É tudo questão de oportunidades e de momentos.
\end{abstract}

Normalmente, os contratos preveem um retorno em cinco anos, mas acabam sendo prorrogados, conforme a necessidade da empresa. "De cinco, já cumpri três anos e três meses. Eu não digo que vou voltar em cinco anos. Pretendo voltar em seis, sete anos, dependendo do que a Elétrica achar. Ou eu volto ou, às vezes, tem, enfim, de ir para outro país também" (E19 - Gerente de Vendas Europa). A demanda da empresa não é necessariamente a que o expatriado volte, pois "o nosso conceito de expatriação é que as pessoas que sejam expatriadas sejam cidadãos do mundo" (E11 - Diretor de GP Corporativa Brasil).

Essa circulação de empregados, no contexto internacional, por meio de expatriações contínuas, configura o conceito de cidadão de mundo (Bohlander, Snell, \& Sherman, 2003). Tal circulação ocorre com empregados brasileiros e internacionais e não tem foco na matriz, mas nas operações internacionais, ou seja, a matriz não recebe estrangeiros, ou os denominados impatriados. Pelo amadurecimento do processo na Elétrica, há perspectiva de que as expatriações sejam um processo contínuo, sem que ocorra o retorno para a matriz. No entanto, a partir do acúmulo de experiências e através de uma oportunidade no país de origem coerente com as competências do empregado, será dado ao início à sua repatriação, como relata o E12 (Diretor Internacional Brasil):

Eu acho que a quantidade de expatriação vai continuar, mas talvez com menos retorno, porque a gente faz um contrato de três ou cinco anos, a maioria estendido. Outros não chegam a concluir porque têm todas as experiências, mas a maioria é de sucesso e alguns a gente convida para voltar, porque é uma oportunidade grande aqui e ele vem.

Os cidadãos do mundo são, normalmente, pessoas com cargos estratégicos. Entretanto, o foco não está no desenvolvimento da pessoa. "Tem, não são todos, mas tem. Têm pessoas que a gente está expatriando para ele dar resultado. Se ele der resultado, ele pode ser repatriado, ou expatriado para outro lugar, para também dar resultado e, de acordo com nosso plano de sucessão, ele pode voltar para um dia suceder alguém" (E11 Diretor de GP Corporativa Brasil). A tendência é que as pessoas não tenham a expectativa de voltar para a matriz: "eu acho que as pessoas vão ter que ir e estabelecer lá fora" (E12 Diretor Internacional Brasil). Há dois casos de empregados que foram para o exterior e que já estão "super integrados e não querem mais saber do Brasil" (E15 - Ex-Diretor Internacional Brasil). Um deles foi para a Bélgica e outro para a Austrália, mas ambos são 
diretores nessas operações. Nesses casos, eles ainda são considerados expatriados da Elétrica com os mesmos benefícios financeiros. É sinalizado, então, que, nessas situações, o empregado deve ser considerado como um local, porém, devido à legislação brasileira e à questão contratual com o empregado, a empresa mantém essa política.

Têm empresas que têm políticas que depois de tantos anos a pessoa tem que tomar uma decisão: ou ele é um expatriado e vai retornar, ou vai para outro lugar, como eu fui para três países. E tem gente que não quer sair mais, pois constituiu família, os filhos estão adaptados, ou qualquer coisa assim e não sai mais. $E$ permanece dentro do expatriado, da lista expatriado, dentro do benefício expatriado. Expatriado é um local, deveria ser um local praticamente. Mas sempre tem aquela parte legal, a pessoa quer se aposentar no Brasil, quer ter uma aposentadoria no Brasil, então têm muitos aspectos que têm que ser analisados em diversos ângulos (E12 - Diretor Internacional Brasil).

Os depoimentos revelam que o desenvolvimento das pessoas é um objetivo secundário da empresa, mas, por vezes, é o objetivo principal do empregado, o qual vislumbra seu crescimento dentro da empresa, conforme exposto em estudos anteriores em Gallon et al. (2013). As principais estratégias para a expatriação são "garantir pessoas confiáveis, dirigindo os negócios da empresa, pessoas competentes e que a estratégia da empresa esteja alinhada entre a matriz e o exterior" (E16 - Analista de GPI Brasil), conforme também apontado por Bartlett e Ghoshal (1992), Black e Gregersen (1999), Tanure et al. (2007), Freitas (2010) e Freitas e Dantas (2011). Isso evidencia que a expatriação está direcionada para a segunda etapa do processo, ou seja, a expatriação em si e não em todo o processo de expatriação, corroborando para um papel pontual da expatriação na organização, como pode ser observado na fala do E16 (Analista de GPI Brasil):

Em menor grau, mas também presente, desenvolver um pouco essas pessoas para os desafios futuros da empresa. O atual presidente da empresa, um ano antes de ele assumir a empresa, foi expatriado para Portugal. Claro, eu não acompanhei na época, mas imagino que o objetivo dessa expatriação fosse dar uma experiência internacional para ele antes de assumir a presidência. Provavelmente ele já estava escolhido para ser o presidente, só foi pedido para ele entender um pouco mais desse dinamismo. Atualmente, há um plano de sucessão. O plano de sucessão é mais ou menos o seguinte: quem são os candidatos para ser o próximo presidente? Bom, tem o negócio dos elétricos, do produto B e do produto C. Quem são os candidatos a ser o diretor da Elétrica do produto D? E assim por diante ele é escalonado nas experiências internacionais.

Nesse sentido, a expatriação é vista como um processo importante: "escolher uma pessoa experiente aqui do Brasil, isso praticamente vale para qualquer expatriação" (E16 Analista de GPI Brasil). Isso porque "onde alguns brasileiros foram com bastão de liderança, eles implantaram. Onde os brasileiros não foram com bastão de liderança, ficou a liderança num local, numa área". Essa divergência está atrelada à informalidade de algumas práticas e objetivos da expatriação na empresa, pois, dependendo do gestor que conduz o processo, há diferentes direcionamentos indicados para o expatriado. Assim, destaca-se a importância de se definir o objetivo da expatriação antes de a pessoa ser enviada para o estrangeiro, conforme apontado por Harzing (2002) e Mccall e Hollenbeck (2003), caso contrário isso pode levar ao insucesso da expatriação (Mccall \& Hollenbeck, 2003). 
Nesse sentido, para evitar que ocorra o comodismo e a dependência da unidade em relação à matriz, o requerimento de um expatriado é avaliado com cautela. Isso também ocorre tanto pelo alto custo envolvido nessa movimentação como pela valorização da mão de obra local.

\begin{abstract}
Se eu quero expatriar alguém, eu preciso submeter uma justificativa perante uma comissão de expatriação, que vai avaliar se aquela pessoa tem o perfil, se faz parte da política Elétrica, faz uma série de análises para garantir que eu não estou simplesmente exportando mão de obra para uma filial, principalmente, as pequenas; quando você se aperta é muito mais fácil pedir socorro para a matriz do que buscar no mercado. Mas não é tão simples assim. Essa comissão, antes de liberar esse cidadão no Brasil, faz toda essa análise para ir, qual é a vantagem, muitas vezes, a filial quer mão de obra barata, acontece, não vou negar, para isso existe o trabalho temporário. 0 trabalho temporário, se tu tem uma necessidade imediata, antes de expatriar, testa. O trabalho temporário te permite isso. Traz a pessoa por alguns meses, não faz um contrato de expatriação de longo prazo. Até para vida do cidadão né, imagina, tu traz o cara, não dá certo. E o contrato é 5 anos. Muitas vezes, tem que repor o cidadão, não é simplesmente descartar. Claro que eu estou exagerando (E13 - Vice-Presidente EUA).
\end{abstract}

Com o aumento da internacionalização da empresa, diversos empregados são demandados a se movimentarem, nacional e internacionalmente. Em consequência disso, a empresa definiu "critérios para estabelecer o que é um 'expatriado Elétrica'" (E16 - Analista de GPI Brasil). O expatriado é uma pessoa de alta competência técnica, pois o objetivo da empresa "não é de mandar operador de produção, pessoa com baixa qualificação, para o exterior para executar trabalho. Qual é o perfil do expatriado? É uma pessoa, um executivo, uma pessoa com grande capacidade técnica, que vai lá para desenvolver um trabalho estratégico para empresa, complexo" (E16 - Analista de GPI Brasil).

O trabalho estratégico citado não corresponde necessariamente a um cargo de gestão. Ele é estratégico, no sentido de o trabalho a ser feito estar determinado, sendo escolhida a pessoa com melhor competência técnica para desenvolvê-lo. A função pode envolver desde um trabalho operacional, como o de solda, até um cargo corporativo, como o de diretor. A primeira demanda de expatriação está relacionada com a área comercial, devido à abertura de escritório de vendas, o qual depois vai sendo desenvolvido, a fim de se tornar uma unidade fabril, quando necessário. Quando há a implantação de uma empresa, surge maior demanda por expatriados da área de produção, como relata o E12 (Diretor Internacional Brasil):

\footnotetext{
A gente tem expatriados em quase todas as áreas: chão de fábrica, qualidade, engenharia, vendas (os primeiros expatriados estavam sempre relacionados à área comercial) e também já estamos com expatriados na área financeira e contábil. Tudo isso para levar os procedimentos porque depois a gente tem que consolidar tudo em um grande resultado.
}

A demanda por expatriados no exterior pode ocorrer de duas maneiras: "tem muita gente que pede, dizem que precisam de brasileiros para tal função, com esse perfil, porque precisam de um cara lá. E tem outros, que a gente diz: 'nós queremos colocar um aí'. Nunca tivemos atritos, fomos sempre bem-vindos" (E12 - Diretor Internacional Brasil). No entanto, não há um momento ou objetivo determinado para o envio de um expatriado, nem uma estratégia principal para o processo, conforme já exposto. 
Esse contexto corrobora para o caráter emergencial e imediatismo da expatriação, implicando em baixa estruturação do processo. Dependendo do contexto e das oportunidades de mercado, há maior ou menor propensão para expatriar. Assim, é salientado que nem sempre a presença de um expatriado está relacionada com o ajuste ao mercado. Há unidades que são mais bem geridas por locais, enquanto outras desenvolvem melhor trabalho sob a gestão de um expatriado, conforme relata o E11 (Diretor de GP Corporativa Brasil):

\begin{abstract}
Nas áreas comerciais são fortes [as demandas por expatriados], assim, são os country managers que a gente chama. Depende do momento, não existe um critério. Nas posições de base têm pessoas que vão bem como expatriados, mas outras filiais comerciais não têm nenhum expatriado. Nós temos alguns casos de expatriação que tem [expatriado] abaixo do gestor. $O$ gestor é um brasileiro, abaixo dele tem metade brasileiro, metade nativo, e a filial não vai bem. Nós temos filiais que tem gestor nativo, metade brasileiro e metade estrangeiro e vai bem. Talvez seja um problema dos nativos ou aqui da base, ou do país, ou do mercado, depende da situação, depende do mercado.
\end{abstract}

A presença do expatriado nem sempre ocorre no início de uma operação, pois é influenciada pelo tipo de empreendimento realizado. Na abertura de um escritório, nem sempre é enviado um empregado brasileiro. Nas unidades em que a Elétrica detém total ou grande parte da gestão, a demanda pelos expatriados é realizada pela matriz brasileira. Nas operações em que sua atuação é minoritária, a solicitação é feita a partir do entendimento e demanda do sócio. O E12 (Diretor Internacional Brasil) salienta que, quando o sócio é uma grande empresa, dificilmente há essa demanda, porém, os sócios com menor representatividade local requerem maior apoio da gestão brasileira, conforme ilustra o próximo depoimento:

\begin{abstract}
A empresa, para pensar em expatriar um trabalhador, está visando o mercado internacional. Nós começamos assim porque a história da internacionalização começa bem antes de pensar em expatriar alguém. Ela começa pelo relacionamento comercial, com algum distribuidor e vai conhecendo o mercado por meio desses parceiros. (...) Com os parceiros, foram sempre iniciativa deles pedirem os expatriados. Nós nunca forçamos. Já tivemos na Nova Zelândia, na África por solicitação deles. Eles dizem: 'eu preciso de um brasileiro para me ajudar'. A África já trabalhava muito sintonizada com a cultura Elétrica porque ele vinha aqui, via o case de sucesso que era a Elétrica e ele copiava muito a gestão (E12 - Diretor Internacional Brasil).
\end{abstract}

Embora a unidade no exterior esteja focada na resposta local com uma atuação mais autônoma, o etnocentrismo da matriz é perpetuado para as unidades do exterior, por meio dos expatriados. "A Elétrica não abre mão dos seus princípios; isso tem que ser levado. Leva tempo. Não é só uma andorinha na fase do verão, como a gente diz. A pessoa vai para lá e começa a disseminar essa cultura Elétrica dentro da organização. E a gente tem tido um sucesso relativamente muito bom nesse sentido" (E12 - Diretor Internacional Brasil). Com o desenvolvimento da unidade e das lideranças locais, é consolidada a autonomia das unidades, tornando a presença do expatriado dispensável. O que direciona para a diminuição da atuação dos expatriados, conforme ocorre o amadurecimento da unidade.

Se tu, sempre que precisar, mandar alguém da matriz para fazer alguma coisa acontecer, estará criando uma relação de dependência que não é muito saudável, a 
não ser que tu queira uma cultura impositiva, não quer nem saber da realidade local. Então, a expatriação tem que ser uma ferramenta, mas não pode ser uma ferramenta em si (E13 - Vice-Presidente EUA).

Esse amadurecimento das unidades e a experiência internacional da Elétrica possibilita entender o contexto externo e agir estrategicamente em relação à demanda de expatriados. Dependendo do amadurecimento da operação, da cultura local e do cargo de destino a ser preenchido, há diferentes decisões implantadas para o preenchimento de cargos internacionais, como relata o E13 (Vice-Presidente EUA):

Nas filiais mais novas, tu dificilmente manda um brasileiro sozinho. É suicídio. Tu normalmente manda um brasileiro e coloca alguém [local] grudado com ele. $\mathrm{Na}$ China, é inevitável. Na Índia, é inevitável. Aqui nos EUA, é um país mais adaptável, está muito próximo da nossa cultura, depende muito da região, óbvio. Na Europa, depende do país. Tem países que não aceitam o estrangeiro, e aí tem a rejeição local. Então, tu também tem que pesar a rejeição local. A gente já teve um caso de uma pessoa de nível relativamente alto na Elétrica, posição gerencial, que foi expatriado e o mercado rejeitou; não por problema de performance, mas por puro preconceito. Isso não vale só para brasileiro.

A expatriação busca atender diversos níveis e objetivos, entre outros: presença de uma pessoa de confiança da matriz; transferência de conhecimento; desenvolvimento de um empregado. Esse direcionamento do processo lembra a perspectiva histórica do conceito de expatriação (Rego \& Cunha, 2009), conforme relata o E15 (Ex-Diretor Internacional Brasil): "é uma empresa, que pela própria origem [familiar], a preocupação dela quando manda alguém para fora é ter alguém de confiança e que faça parte da empresa de alguma maneira, da história".

A mobilidade do empregado brasileiro é regulamentada pela legislação trabalhista. Há uma lei específica quanto à mobilidade do empregado para o exterior. Ela configura um empregado como expatriado a partir de 90 dias fora do seu contexto de origem, o qual deve ser recompensado quando isso ocorrer. Com o benefício legal de $25 \%$ para ambos os casos, por vezes, o conceito de expatriação pode ser ampliado para a movimentação intranacional do empregado. A Elétrica não faz tal distinção. Ela cumpre a lei em ambos os casos, mas só considera expatriação quando o empregado é enviado para outro país.

Essa diferenciação é importante, pois o aumento salarial e os benefícios impostos pela legislação brasileira permitem que o expatriado tenha um bom retorno financeiro, estando seu contrato de trabalho vinculado ao país de origem. "No meu caso de expatriado, eu tenho um contrato de fornecimento aqui, que eu recebo um salário baixo em relação ao que eu tenho lá, porque o que eu tenho aqui é uma ajuda de custo, porque o meu salário base está lá" (E17 - Gerente de Mercado Internacional Europeu). Portanto, os expatriados são alocados nas unidades de destino como prestadores de serviço para aquela empresa.

A empresa tem desenvolvido diferentes ações para atender os expatriados, principalmente, para os que vão a países com um contexto muito diferente daquele que os brasileiros estão acostumados. "Nosso refeitório na Índia é terceirizado por uma empresa francesa de alimentação, mundialmente famosa, e foi contratada uma brasileira para ensinar receitas brasileiras para o chefe de lá para preparar a comida dos expatriados" (E16 - Analista de GPI Brasil). Isto aconteceu porque, na Índia, a alimentação é um aspecto crítico, devido às precárias condições de higiene, aos fortes temperos e aos costumes culturais. 
As empresas tendem a implantar unidades em mercados culturalmente próximos, para evitar delongas que retardem o amadurecimento da subsidiária. No caso da Elétrica em Portugal, essa aproximação não facilitou a entrada da empresa brasileira no mercado lusitano. A resistência de trabalho dos empregados portugueses - "dos colonizados comprarem a empresa dos colonizadores" (E13 - Vice-Presidente EUA) - e a própria transição de gestão em uma aquisição tornaram a experiência em Portugal desafiadora, inclusive maior do que em alguns mercados críticos e distantes culturalmente do Brasil, como a Índia. Essa situação é relatada por diversos entrevistados da Elétrica (E10 Supervisor de vendas internacionais Brasil, E13 - Vice-Presidente EUA e E14 - Assistente Técnico Europa). Tal panorama mostra a necessidade de haver um treinamento cultural, independentemente do país de destino.

O contexto brasileiro influencia o panorama da Elétrica, quando o assunto é expatriação. Existem alguns fatores estruturais que podem interferir nesse processo, principalmente em cidades de pequeno porte, como aquela em que está localizada a matriz da Elétrica, como relata o E12 (Diretor Internacional Brasil): "trazer estrangeiros para cá [Brasil]? Não vou dizer que não é plano da empresa. Já experimentamos. Tivemos dois ingleses que moraram aqui na cidade que tinham mobilidade, mas na hora que você coloca família, complica". Assim, a infraestrutura necessária para a adaptação de uma pessoa estrangeira pode ser conseguida facilmente em cidades como São Paulo e outras capitais, mas nem sempre em lugares como a cidade que sedia a Elétrica.

Imagine-se que um empregado é expatriado ao Brasil com sua família (cônjuge e filhos) e todos falam apenas o idioma inglês. Ele precisa estar em um local com condições estruturais para a ambientação de sua família, com uma escola bilíngue para os filhos e com oportunidades de emprego para o cônjuge. Isso não seria problema em uma cidade como São Paulo ou Rio de Janeiro, porém configura-se como uma dificuldade em localidades menores. Ressalva-se, no entanto, a dificuldade de trazer expatriados para cidades como São Paulo e Rio de Janeiro pela existência da violência e da repercussão que isso tem no exterior.

Diante dos diversos fatores que envolvem o processo, a expatriação envolve momentos de "improvisação, tanto pessoal como da empresa" (E15 - Ex-Diretor Internacional Brasil). Por parte da empresa, a improvisação ocorre tanto no convite para expatriar, quando é dado um prazo curto para a tomada de decisão e a preparação para viajar, como na questão de retorno. Isso porque a expatriação "muitas vezes, não é muito voltada para o expatriado; mais é uma necessidade momentânea mesmo" (E19 - Gerente de Vendas Europa). "Aí o presidente da Elétrica chamou o empregado: 'é o seguinte, nós estamos convencidos: temos que montar uma empresa lá na Austrália. Na terça-feira tu te apresenta lá. Tu é o novo presidente'”' (E15 - Ex-Diretor Internacional Brasil).

Era para ficar só dois anos, e fui convidado a ficar. Daí, quando chegou ao fim do primeiro ano, eu tinha que ir treinar alguém para ficar no meu lugar e nós não encontramos naquele primeiro ano. Então, eles me disseram assim: 'ok, então, vamos fazer um contrato de 4 a 6 anos'. Claro que nos 4 anos já colocaram para 6 anos. E, ok, fico até o fim de 2013. Daí no meio do ano eles já me perguntaram se eu poderia ficar mais 2 anos. Agora que nós detectamos quais são as pessoas que podem, eventualmente me substituir, nós estamos mais ou menos treinando essas pessoas (E17 - Gerente de Mercado Internacional Europeu). 
Ressalta-se que a necessidade em descentralizar o conhecimento do indivíduo e em promover sua dissolução por meio de práticas organizacionais, pois, caso a pessoa se desligue da empresa, esse conhecimento não sairá com ela. Falta essa visão para a Elétrica no processo de expatriação. O E13 (Vice-Presidente EUA) relata a existência de "sessões de feedback, onde eles [repatriados] falam para todo mundo das suas experiências. Isso ajuda bastante essa troca de experiência". No entanto, poucas ações foram levantadas na pesquisa com o direcionamento para a retenção e a perpetuação do conhecimento. Isso pode estar relacionada com a área à qual o entrevistado citado está vinculado: a engenharia, que, bem como a área de vendas e assistência técnica, tem maior fluidez de informações que outras áreas, de acordo com o depoimento dos entrevistados.

Com o retorno dos expatriados para a matriz, a GP tem percebido as lacunas do processo e buscado superá-las. O processo de expatriação vem amadurecendo desde o início da primeira missão, na percepção do E12 (Diretor Internacional Brasil). Há, portanto, um direcionamento da GPI para ampliar a expatriação e incorporar a repatriação nesse processo. Isso permite analisar a expatriação em três fases, mas com foco no indivíduo - na retenção do empregado.

Você não tem ideia como é fazer uma gestão de executivos a nível internacional, isso envolve muito a empresa. A gente é bastante cobrado em relação a isso, porque são as pessoas que comandam a empresa. Então, ela não pode perder essas pessoas, elas têm uma quantidade de informações importantes, chaves. Uma coisa é talvez me perder - eu sei bastante informação confidencial da empresa mas não sei tanto. Agora, um executivo, ele tem acesso a questões de preços, estratégias da empresa, como é que a empresa se posiciona, como é que ela remunera, então, é muito importante essas pessoas. Além disso, eu acho que a empresa se tornou mais visível no mercado, então, isso aumenta a atratividade dos funcionários da empresa. Imagine o seguinte: uma empresa do tamanho da Elétrica, mas que não seja internacionalizada; a atratividade de funcionários no mercado vai ser bem menor do que trabalhar em uma empresa multinacional. Então, a empresa tem que ter estratégias mais eficientes para reter os funcionários, remunerando, oferecendo benefícios, plano de carreira (E16 Analista de GPI Brasil).

Por todo exposto, o processo de expatriação aborda diversas questões, tais como estratégia; competência e desenvolvimento da pessoa; custo; benefícios; salário; crescimento do empregado na empresa; entre outros. A política e as práticas de expatriação destacam-se pelo caráter informal, o que propicia descontentamento, desconfiança e impessoalidade no processo. A Figura 1 apresenta e resume as principais práticas citadas e destacadas sobre expatriação.

\begin{tabular}{|c|l|}
\hline Políticas e Práticas & \multicolumn{1}{c|}{ Descrição } \\
\hline & $\begin{array}{l}\text { Dificilmente há uma seleção aberta para todos os empregados. Havendo demanda da } \\
\text { unidade ou necessidade corporativa em melhorar resultados e expandir a cultura da } \\
\text { empresa, é indicado o cargo a ser preenchido. É realizado, então, o levantamento, } \\
\text { Análise do perfil, } \\
\text { recrutamento e } \\
\text { seleção }\end{array}$ \\
$\begin{array}{l}\text { serem expatmente por meio de indicação dos gestores, das pessoas com possibilidade de } \\
\text { Normalmente, os cargos a serem preenchido são de gestão, o que diminui o número } \\
\text { de candidatos disponíveis. Há, no entanto, tendência de que essas práticas sejam } \\
\text { realizadas com bastante cautela para evitar o retorno precoce. }\end{array}$ \\
\hline $\begin{array}{c}\text { Análise do perfil } \\
\text { familiar }\end{array}$ & $\begin{array}{l}\text { Não há. Depois que o expatriado foi escolhido, a família assume papel secundário: } \\
\text { acompanhar o expatriado. }\end{array}$ \\
\hline
\end{tabular}




\begin{tabular}{|c|c|}
\hline $\begin{array}{l}\text { Auxílio/ } \\
\text { acompanhamento } \\
\text { psicológico para o } \\
\text { empregado e } \\
\text { família }\end{array}$ & $\begin{array}{l}\text { Não é disponibilizado no contrato de expatriação, mas os entrevistados relataram } \\
\text { que, quando solicitaram esse auxílio para a empresa, rapidamente, foi } \\
\text { disponibilizado. }\end{array}$ \\
\hline Contrato & $\begin{array}{l}\text { Há um contrato que especifica salário e benefícios a serem recebidos e tempo de } \\
\text { expatriação. Esse contrato é vinculado à empresa de origem. Não há quebra de } \\
\text { vínculo empregatício. }\end{array}$ \\
\hline $\begin{array}{l}\text { Trabalho } \\
\text { desenvolvido }\end{array}$ & $\begin{array}{l}\text { Não há nada formalizado. Quando a proposta é realizada para o empregado, há uma } \\
\text { conversa informal sobre o trabalho a ser assumido. No entanto, isso muda conforme } \\
\text { o gestor que está coordenando o processo. }\end{array}$ \\
\hline $\begin{array}{l}\text { Remuneração e } \\
\text { benefícios }\end{array}$ & $\begin{array}{l}\text { Aumento salarial obrigatório de } 25 \% \text { e mais alguma porcentagem relacionada ao } \\
\text { cargo assumido (referente à quantia recebida no Brasil). São fixados diversos } \\
\text { benefícios, como auxílio de custos, carro, telefone, aluguel da casa, escola para os } \\
\text { filhos, entre outros, de acordo com o cargo assumido. Alguns expatriados (tanto da } \\
\text { Elétrica como da Metálica e da Ferro) recompensam financeiramente o cônjuge que } \\
\text { sai do emprego no Brasil para acompanhar o expatriado. A Metálica, preocupada com } \\
\text { um possível deslumbramento advindo do aumento salarial, disponibiliza assessoria } \\
\text { financeira para que o expatriado faça seu planejamento financeiro. }\end{array}$ \\
\hline Custo & $\begin{array}{l}\text { Custo quatro vezes mais que um empregado local. Ressalta-se que essa informação } \\
\text { está baseada em pesquisas científicas norte-americanas, às quais a empresa tem } \\
\text { acesso. }\end{array}$ \\
\hline Documentação & $\begin{array}{l}\text { Não há comunicação sobre este item entre a GPI do país de origem com a de destino, } \\
\text { o que causa diversos percalços aos expatriados. }\end{array}$ \\
\hline $\begin{array}{l}\text { Treinamento } \\
\text { cultural, linguístico } \\
\text { técnico e gerencial }\end{array}$ & $\begin{array}{l}\text { O treinamento linguístico é disponibilizado para o empregado e sua família, os demais } \\
\text { treinamentos são responsabilidade do empregado. }\end{array}$ \\
\hline Acolhimento & Não há nada formalizado, mas deve ser realizado pelo gestor do país de origem. \\
\hline Gestão de carreira & $\begin{array}{l}\text { Não há. No contrato de expatriação, é garantida a ocupação do cargo anterior à } \\
\text { viagem do empregado. De modo informal, em alguns casos, é possibilitada a } \\
\text { expectativa de carreira na empresa, caso o empregado proporcione bons resultados } \\
\text { em sua missão. Esse resultado, de modo informal, não é baseado no trabalho } \\
\text { desenvolvido no exterior, mas no desempenho da unidade. }\end{array}$ \\
\hline $\begin{array}{l}\text { Tributação dos } \\
\text { rendimentos no } \\
\text { exterior }\end{array}$ & $\begin{array}{l}\text { A Elétrica, Metálica e Ferro ressaltam que a legislação brasileira não é clara, } \\
\text { permitindo diversos entendimentos quanto a essa questão. A Elétrica proporciona } \\
\text { acompanhamento jurídico para auxiliar nessa questão. }\end{array}$ \\
\hline $\begin{array}{l}\text { Práticas informais } \\
\text { que ainda não } \\
\text { foram adotadas }\end{array}$ & $\begin{array}{l}\text { São feitas diversas viagens pelos empregados para mascarar a ausência do visto de } \\
\text { trabalho; o expatriado acaba escolhendo um gestor como responsável por seus } \\
\text { problemas e expectativas; a seleção informal ocorre em função do imediatismo do } \\
\text { preenchimento do cargo, devido a diversas razões, como o despreparo da empresa } \\
\text { para o retorno de um expatriado ou a não adaptação de um expatriado no exterior. A } \\
\text { seleção informal também pode ocorrer, entre outros fatores, por haver poucas } \\
\text { pessoas com tal preparação e disponibilidade ou até um eventual desconhecimento } \\
\text { da empresa sobre as competências de seus empregados. }\end{array}$ \\
\hline
\end{tabular}

Figura 1. Principais políticas e práticas de expatriação

Fonte: Elaborada pelos autores (2017).

Ademais, há o surgimento de novas práticas, pois a Elétrica está estruturando o processo de expatriação para dar melhor suporte a seus empregados no exterior. Conforme o processo foi sendo desenvolvido, diversas práticas foram criadas, como a análise da mão de obra no exterior e, principalmente, em relação ao retorno dos expatriados para a matriz. Algumas práticas foram abordadas pelos entrevistados, as quais, no entanto, não são implantadas pela GPI, são elas: orientações locais, adaptação ao país estrangeiro, comunicação com a empresa de origem, avaliação de desempenho, gestão do 
conhecimento, aprendizado individual e organizacional, trabalho a ser desenvolvido na repatriação, orientações sobre as mudanças da empresa e valorização da pessoa/ aprendizado adquirido.

\section{Considerações Finais}

Frente à expansão internacional das empresas e, consequentemente, da mobilidade de empregados, novos desafios são discutidos na GP e na gestão de expatriados. Para tanto, o presente estudo teve o propósito de analisar as políticas e práticas da GP no processo de expatriação em uma empresa brasileira.

As principais práticas relacionadas ao processo de expatriação foram citadas: análise da demanda de mão de obra no exterior; análise do perfil do empregado e de sua família; auxílio e acompanhamento psicológico para o empregado e sua família; recrutamento e seleção; contrato; trabalho a ser desenvolvido; remuneração; benefícios; documentação; preparação e treinamento (técnico, gerencial, cultural e linguístico); saúde; custo; acolhimento e orientações locais; adaptação ao país estrangeiro; comunicação com a empresa de origem; avaliação de desempenho; gestão do conhecimento; surgimento de práticas informais que ainda não foram administradas pelas empresas (de origem e de recebimento); aprendizado individual e organizacional; gestão de carreira; orientações sobre as mudanças da empresa; tributação dos rendimentos no exterior; valorização da pessoa/ aprendizado adquirido; necessidade de novas práticas para os expatriados. Nem todas estas práticas citadas estão sendo aplicadas formalmente na empresa, porém, em algum momento, foram citadas e identificadas como importantes no processo.

A expatriação tem sido um processo importante na interface dessa relação entre matriz e subsidiária, pois, através do expatriado, a matriz leva seus valores, cultura, políticas e práticas para a subsidiária, mas também acaba tomando consciência de tais aspectos implantados e desenvolvidos pela subsidiária. O expatriado leva esse conhecimento para a matriz no retorno da sua expatriação e cabe à matriz desenvolver estratégias para que as duas empresas, e as demais unidades de negócios, tenham objetivos consoantes. Compreendendo esse processo no nível operacional, a relação matriz-subsidiária também é importante, pois elas compartilham o mesmo empregado por determinado tempo e, por consequência, a gestão desta pessoa.

Com uma contribuição organizacional pontual - fruto de uma estratégia operacional ao invés de uma organizacional -, a expatriação é tratada como uma viagem, com foco na segunda fase do processo. Isso corrobora com políticas e práticas de expatriação menos enfáticas na terceira fase do processo: a repatriação, contribuindo para um papel passivo do conhecimento da subsidiária e pouca contribuição da expatriação para a matriz. A estruturação desse processo é importante para que seja dado o suporte necessário aos empregados que estão trabalhando em diferentes países, para obter uma percepção mais ampla da expatriação e para ligá-la à estratégia de internacionalização e, assim, a expatriação ter um impacto estratégico na empresa.

Verifica-se, assim, que as pessoas ligadas à expatriação não a mencionam como um processo, mas ao relatarem as etapas, manifestam terem a percepção de processo. Ainda não há uma noção de processo de expatriação implantada nas organizações, mas, quando posta em prática, não é possível dissociar uma etapa da outra, levando ao entendimento de processo. A expatriação da Elétrica tem a perspectiva de processo, mas ainda não é reconhecida e tratada como tal. Essa perspectiva não é formalizada na empresa, muito 
devido à imaturidade da GP no contexto internacional e de políticas e práticas de expatriação de pouca expressão.

A GP da Elétrica precisa, portanto, englobar diferentes contextos para desenvolver suas políticas. A GP corporativa e a pequena e burocrática GPI contribuem para o direcionamento de uma atuação passiva das subsidiárias na gestão da organização. Esse contexto evidencia o lento amadurecimento internacional da empresa. As práticas que poderiam contribuir para tal amadurecimento são focadas no conhecimento da matriz, como o manual de instrução.

A estratégia de expatriação está focada em preencher uma demanda local buscando ter expatriados para desenvolver as unidades até que elas tenham autonomia para serem geridas por empregados locais. A Elétrica está aprendendo com as repatriações que começaram a acontecer e planeja o melhoramento de políticas e práticas relativas a esses empregados. Frente à sinalização da direção da empresa em aprimorar o processo de expatriação, resgata-se o estudo de Vianna (2008) com sete empresas brasileiras que também sinalizaram a importância da estruturação da expatriação para que ela adquira valor estratégico. Os entrevistados do estudo afirmaram que a área estava sendo reestruturada para alcançar esse valor estratégico. Aparentemente, essa reestruturação está ocorrendo há sete anos: apesar de não serem as mesmas empresas, é um padrão de resposta que se encontra, não somente no presente estudo e na dissertação de Vianna (2008), como também em Lima e Braga (2010) e Gallon (2011). Os estudos que buscam questionar a estrutura da GP para apoiar a expatriação acabam encontrando áreas 'em desenvolvimento ou a serem desenvolvidas'.

Como sugestões de pesquisas futuras, é evidente a importância da análise do modo de entrada da empresa em outro país. Dependendo do tipo de negócio no país estrangeiro, o espaço da matriz nas decisões da subsidiária pode variar. No caso de joint venture, leva-se em consideração tanto o contrato comercial estabelecido como a porcentagem de aquisição. No caso de uma participação minoritária, a demanda dos empregados brasileiros é realizada pelo parceiro empresarial. Tal decisão pode impactar nos objetivos estratégicos para a expatriação, mas não exime a empresa de desenvolver o processo de expatriação sem planejamento.

Por todo exposto, ressalta-se empiricamente o desvinculamento do processo de expatriação da estratégia de internacionalização das empresas, resultando em um processo mal planejado e de caráter operacional, acarretando a perda de um importante conhecimento organizacional e internacional.

Assim, a expatriação é um processo de difícil mensuração e, frequentemente, a sua contribuição para a empresa passa despercebida. Evidencia-se, portanto, um processo complexo com muitas possibilidades, mas também com grandes desafios, nem sempre inerentes ao processo de expatriação - nível operacional, mas a uma percepção do processo no nível organizacional.

\section{Referências}

Bardin, L. (2009). Análise de conteúdo. 3. ed. Lisboa, Portugal: Edições 70.

Bartlett, C. A., \& Ghoshal, S. (1992). Managing Across borders: The Transnational Solution. Harvard Business School Press, Boston, Massachusetts.

Black, J. S., \& Gregersen, H. B. (1999). The right way to manage expats. Harvard Business Review, 77(2), 52-57. 
Bohlander, G., Snell, S., \& Sherman, A. (2003). Administração de Recursos Humanos. São Paulo: Pioneira Thomson Learning.

Cechella, D. C. (2009). Os investimentos brasileiros em Portugal: um estudo de três casos. In: J. R. Silva, \& A. C. Barbosa. Estado, Empresas e Sociedade: Um Mosaico LusoBrasileiro. Lisboa: Edições Colibri.

Deresky, H. (2004). Administração global: estratégica e interpessoal. Porto Alegre: Bookman.

Empresa Elétrica. (2014). Material Interno. Recuperado em 03 junho, 2014, de http://www.empresaeletrica.net/br.

Flick, U. (2009). Métodos qualitativos na investigação científica. Lisboa: Monitor.

Freitas, M., \& Dantas, M. (2011). O Estrangeiro e o novo grupo. Revista de Administração de Empresas, 51(6), 601-608.

Freitas, M. (2010). Expatriação Profissional: o desafio interdependente para empresas e indivíduos. Revista Eletrônica Gestão e Sociedade, 4(9).

Fundação Dom Cabral. (2010). Ranking Transnacionais Brasileiras 2010. Repensando as Estratégias Globais. Recuperado em 03 junho, 2013, de http://www.fdc.org.br/pt/Documents/ranking_transnacionais_2010.pdf.

Gallon, S., \& Antunes, E. D. (2015). Processo de expatriação: um modelo com fases e práticas. Revista Eletrônica de Estratégia \& Negócios, 8, 54-85.

Gallon, S. (2011). Repatriação e carreira: possibilidades e desafios. Dissertação (Mestrado em Administração), Programa de Pós-Graduação em Administração, Universidade Federal do Rio Grande do Sul, Porto Alegre.

Gallon, S., Scheffer, A. B. B., \& Bitencourt, B. M. "Eu fui, voltei e ninguém viu": um estudo sobre a expectativa de carreira após a repatriação em uma empresa brasileira. Cadernos EBAPE.BR, 11(1), p. 128-148, 2013.

Harzing, A. W. (2002). Are our referencing errors undermining our scholarship and credibility? The case of expatriate failure rates. Journal of Organizational Behavior, 23(1), 127-148.

Homem, I. D., \& Dellagnelo, E. H. L. (2006). Novas formas organizacionais e os desafios para os expatriados. Revista de Administração de Empresas (eletrônica), 5(1), jan./jun.

Janghorban, R., Roudsari, R. L., \& Taghipour, A. (2014). Skype interviewing: The new generation of online synchronous interview in qualitative research. International Journal of Qualitative Studies on Health and Well-being, 9.

Kubo, E. K., \& Braga, B. M. (2013). Ajustamento intercultural de executivos japoneses expatriados no Brasil: um estudo empírico. Revista de Administração de Empresas, 53(3), 243-255.

Lazarova, M., \& Caligiuri, P. (2004). Repatriation and Knowledge Management. In: A. Harzing, \& J. V. Ruysseveldt. International Human Resource Management. London: Sage Publications.

Lima, M. B., \& Braga, B. M. (2010). Práticas de Recursos Humanos do Processo de Repatriação de Executivos Brasileiros. Revista de Administração Contemporânea, 14(6), 1031-1053.

Mccall, M., \& Hollenbeck, G. P. (2003). Desenvolvimento de Executivos Globais. As lições da experiência internacional. Porto Alegre: Bookman.

Mendenhall, M., \& Oddou, G. R. (1985). The dimensions of expatriate acculturation: A review. Academy of Management Review, 10(1), 39-47. 
Mercer. (2010). International Assignment Survey - Portugal. Recuperado em 10 junho, 2013, de http://www.mercer.com.br/press-releases/1387345.

Pereira, N. A., Pimentel, R., \& Kato, H. T. (2004). Expatriação e estratégia internacional: o papel da família como fator de equilíbrio na adaptação do expatriado. In: Encontro Nacional dos Programas de Pós-Graduação em Administração, 28. Curitiba. Anais... [S.I.]: CDROM.

Prestes, V., \& Rosembrock, M. (2015). O Processo de Expatriação: as pessoas no contexto internacional. Caderno Científico CECIESA - GESTÃO, 1(1), 131-141.

Rego, A., \& Cunha, M. P. (2009). Manual De Gestão Transcultural de Recursos Humanos. Lisboa: Editora RH.

Schulze, J., \& Bustamante, M. T. (2015). A expatriação como fonte de vantagem competitiva. REIS - Revista de Extensão e Iniciação Científica UNISOCIESC, 2(1).

Schuler, R. S., Budhwar, P. S., \& Florkowski, G. W. (2002). International human resource management: review and critique. International Journal of Management Reviews, 4(1), 41-70.

Sebben, A. (2009). Expatriados.com: um desafio para os RHs interculturais. Porto Alegre: Artes e Ofícios.

Smale, A. (2008). Global HRM integration: a knowledge transfer perspective. Personnel Review, 37(2), 145-164.

Tanure, B., Evans, P., \& Pucik, V. (2007). A Gestão de Pessoas no Brasil. Virtudes e Pecados Capitais. Estudos de Caso. Rio de Janeiro: Elsevier.

Tung, R. (1981). Selection and training of personnel for overseas assignments. Columbia Journal of World Business, 16(1), 68-78.

Tungli, Z., \& Peiperl, M. (2009). Expatriate practices in German, Japanese, U. K. and U. S. multinational companies: a comparative survey of changes. Human Resource Management,48(1), 153-171.

Vianna, N. P. (2008). Uma análise sobre os processos de expatriação e repatriação em organizações brasileiras, 2008. 127f. Dissertação (mestrado em Administração), Programa de Pós-Graduação em Administração, Universidade do Vale do Rio dos Sinos, São Leopoldo.

Vianna, N. P., \& Souza, Y. S. (2009). Uma análise sobre os processos de expatriação e repatriação em organizações brasileiras. Revista de Administração e Contabilidade da Unisinos (BASE), 6(4), 340-353.

Yin, R. (2010). Estudo de caso: planejamento e métodos. Porto Alegre: Bookman.

Zwielewski, G., \& Tolfo, S. (2016). Qualidade de vida no trabalho de profissionais expatriados para índia e china. REAd, 2, 510-542. 